\title{
Firm Size As A Moderation Factor: Testing The Relationship of Capital Structure With Dividend Policy
}

\author{
Akhmadi $^{1 *}$, Bambang Mahmudi ${ }^{2}$, Moh Muksin $^{3}$, Indra Suhendra ${ }^{4}$, and Rina $\mathrm{F}^{5}$ \\ 1, 2, 3, 4, 5 Universitas Sultan Ageng Tirtayasa, Serang, Indonesia
}

\begin{abstract}
This study examines size as a variable that can strengthen and weaken the relationship between debt policy and dividend policy. Presearch using a sample of 26 companies of 65 population Basic industrial and chemical manufacturing companies listed on the Indonesia Stock Exchange in 2011-2015, which is determined by purposive technique. The variables observed include debt policy as an independent variable, dividend policy as the dependent variable, and firm size as a moderating variable. The analysis tool uses regression moderating analysis (MRA). The results prove that the Debt to Asset Ratio (DAR) has a negative and insignificant effect on the Dividend Payout Ratio $(D P R)$, firm size negatively moderates and there is a significant relationship between capital structure and dividend policy.
\end{abstract}

Keywords: DAR, DPR, Firm Size, ROE.

\section{Introduction}

The capital market is an alternative long-term investment option, where one of the products that often gets the attention of investors is stocks because of the investor's expectation of stock returns, in the form of capital gains and dividends. Regarding dividends, this return is usually expected by investors who are oriented towards longterm returns, whose mechanism is decided at the general meeting of shareholders (GMS). According to Suad Husnan and Enny Pudjiastuti (2002: 333), dividend policy is a policy that concerns the use of profit which is the right of shareholders, basically the profit can be divided as dividends or retained to be reinvested. Meanwhile, according to Brigham \& Houston (2001), the optimal dividend policy is a dividend policy that can create a balance between current dividends and future growth that can maximize the company's stock price.

Regarding dividend policy, there are several relevant theories including the bird in the hand theory, which explains that investors who prefer dividends have the view that dividends have less risk and a more certain rate of return compared to capital gains. While inagency theoryIt is explained that investors generally want a relatively stable dividend distribution (steady stream) and increase in the future, because dividend stability can increase investor confidence in the company and support the company's performance prospects (profitability), thereby reducing investor uncertainty in investing funds in the company (Philippatos and Sihler, 1991) in Ambarwati (2012).

Many factors influence the dividend ratio. According to Hanafi (2004), factors that can influence dividend policy are investment, profitability, liquidity, access to markets, income stability, and restrictions. While Levy and Sarnat (1990) in Van Horn (1986), the factors that influence dividend decisions include profitability, liquidity position, debt capacity, capital structure, prohibition on debt covenants, level of company expansion, level of company profit, firm stability, ability to enter. capital market, controlling group actors, the position of shareholder as taxpayer, tax on profits that were done wrongly, and the inflation rate.

Based on this explanation, it is clear that dividend policy is influenced by many factors, but several previous empirical researchers have presented dividend policy

* Corresponding author. Email address: akhmadi@untirta.ac.id 
related to capital structure. Research by Dewi et al (2012), proves that capital structure has a negative effect on dividend policy. Meanwhile Siswantini (2014) and Sulistyowati et al (2013) prove that capital structure has a positive effect on dividend policy. A very different result was stated by Gita and Rohmawati (2010, which proved that the capital structure did not have a significant effect on dividend policy).

Based on the explanation above, it is clear that there is still a gap in the relationship between capital structure and dividend policy. Thus the relationship cannot be said to be an established relationship, but it still creates ambiguity (confusion). The gap that occurs is believed to be due to the presence of other variables that influence this relationship. Based on the search for several references related to several previous studies leadingfirm size as a variable that can affect the relationship between capital structure and dividend policy.Research by Musiega et.al (2013), proves that Size is able to mediate the relationship between the leverage variable and dividend policy.

Consider existing research gaps, the researchers are interested in conducting research which is different from the previous research, namely by adding the Firm Size as a moderating variable. Based on the research problems that have been stated, the objectives of this study are: is there an effect of capital structure on dividend policy? Is there an effect of profitability on dividend policy? Is the effect of capital structure and profitability on dividend policy moderated by firm size?

\section{Literature Study \\ Signalling Theory}

Signaling Theory, Bhatacharya (1972) inIrham Fahmi (2013),emphasizes the importance of the information issued by the company on investment decisions outside the company. Signalling theoryin Suharli (2006), management will pay dividends to signal the company's success in posting profits. Furthermore, Weston and Copeland, 1997 in Nursandari (2013), the level of company profit is a basic element of dividend policy so that financial ratio analysis affects dividend policy.

\section{Agency Theory}

Jensen and Meckling (1976) in Najmudin (2011), describes the relationship between separation of ownership and company control. Describing the conflict between the principal and the agent, which states that agency costs are the sum of a) expenses for monitoring by the owner (principal), b) expenses for binding by the agent, and c) other costs related to company control. The existence of this separation will create a conflict of interest between shareholders and managers.

\section{Packing Order Theory}

Inner order pecking theory Najmudin (2011), starting from the premise that companies use internal funding when available, and choose to issue debt over equity when external funds are needed. Issuance of new shares is a last resort.Maidah (2016), explained that if the use of internal funds is insufficient, then the second alternative is to use debt. This stigma means that the larger the size of the company indicates that the company has a higher number of assets and tends to use larger external funds. along with the increasing growth of the company.

\section{Dividend Policy}

Dividend is a part of profit which is the right of shareholders regarding their ownership in a company. Halim (2015: 7), dividend is the distribution of profits given by the company that issued the shares for the profits generated by the company. Generally, dividends are an attraction for shareholders with a long-term orientation. There are different types of dividends, according toMusthikawati (2010) in Nursandari (2013), namely cash dividend, property dividend, script dividend, liquidating dividend, 
and stock dividend.

Dividend policy maccording to Sudana (2011: 164), relates to determining the percentage of net profit after tax that is distributed as dividends to shareholders. WhileMulyawan (2015)Dividend policy is a decision to share the profit earned by the company to shareholders as dividends or to hold it in the form of retained earnings to be used as investment financing in the future.

Capital Structure

Wild, 2005 in Mulyawan (2015), capital structure is a combination of long-term debt and securities used by a company to finance its operational activities. Irham Fahmi (2016), capital structure is a description of the form of the company's financial proportion, namely between the capital owned by long-term liabilities and equity (shareholder's equity) which is a source of financing for a company. Raharjaputra (2011: 296) The capital structure is the proportion between long-term debt and equity in order to finance its investment (operating assets). Capital structure is measured using a capital structure ratio known as the leverage ratio (Nuswandari, 2013). According to Kasmir (2012: 151), the leverage ratio is a ratio used to measure the extent to which the company's assets are financed with debt.

\section{Firm Size}

The size of the company is the size of the company seen from the size of its equity, firm value, or the result of the total asset value of a company Riyanto, 2011 in Agustiniet al, 2015). Sudarsi, 2002 in Prasetia et al (2014), company size is the natural $\log$ of total assets. Meanwhile, Huang (2002) in Damayanti (2013) states that company size is a reflection of the size of the company as measured by the natural logarithm of Sales.

\section{Hypothesis Development Effect of Capital Structure on Dividend Policy}

Jensen et al (1992) supported by Megginson (1997) and Chen and Steinler (1999) in Dewi (2008), explained that debt policy negatively affects dividend policy. Companies with high levels of debt will try to reduce agency cost of debt by reducing their debt. Debt reduction can be done by financing investments with internal sources of funds so that shareholders will give up their dividends to finance their investments. The same thing was statedKalay (1982) in Suhadak and Darmawan, (2011), that companies that use high leverage will cause the company to reduce or not increase its dividend payments (Suhadak and Darmawan, 2011: 170).

Jensen et. al (1992) inDewi (2008), debt policy has a negative effect on dividend policy because the use of debt that is too high will cause a decrease in dividends where most of the profits will be allocated as reserves for debt settlement. Agency theory in Dewi and Sedana (2012), suggests a negative relationship between capital structure and dividend policy where debt is a way to reduce agency conflicts. Companies that have debt, then the company will be forced to remove the available cash from the company to pay interest on debt and pay off debt before distributing the dividend policy.

The relationship between model structure and dividend policy is empirically explained Dewi (2011), which provesthat the capital structure has a significant negative effect on Dividend Policy. These results are supported by several subsequent researchers, namely Sumiadji (2011), Dewi and Sedana (2012), Vo and Nguyen (2014), Mandala (2014), and Pramana et al (2015), who in essence explain that to reduce agency problems. then part of the company's funds must be willing to pay installments and interest on debt, so there is a tendency to reduce its priority to increase the dividend ratio.

Based on the explanation above, then the research hypothesis 1 (H1) can be formulated, namely: $\mathrm{H} 1$ : The higher the capital structure, the smaller the dividend ratio 


\section{The Effect of Capital Structure on Dividend Policy Moderated by Firm Size.}

Sjahrial (2008) explains that companies with a larger size have greater confidence in obtaining sources of funds, so that it will be easier to obtain credit from outside parties.

Empirically, the relationship between firm size and capital structure is explained by Sunarya (2013), which proves that firm size strengthens the relationship between capital structure and dividend policy. There is a tendency to use larger loan amounts compared to smaller companies. Research results that are also relevant to the research of Sunarya (2013), presented by Elsa (2012), Joshua and Komang (2013), Tariq (2015), Maidah (2016), Karadeniz et al (2011), Tatik and Budiyanto (2015), Rehman (2016), and Trinh and Phuong (2016), who prove that company size determines the company's capital structure.

Agency TheoryVogt (1994) in Dewi (2008), identifies that the size or size of the company plays a role in explaining the dividend payout ratio in the company. Empirically Khoiro et al (2013), which proves that company size has a significant and positive influence on dividend policy. The positive significant effect explains that companies with a higher size tend to have an increase in dividend policy.

Pecking order theory,Smith and Warner, 1979 in Hadianto (2007), large companies can easily finance their investment through the capital market because of the small information asymmetry that occurs. Investors can get more information from large companies when compared to small companies. So, obtaining funds through the capital market makes the proportion of debt smaller in the capital structure. Titman and Wessel 1988 in Hadianto (2007), that the issuance of equity to small companies costs more than large companies. In other words, the larger the company size, the cheaper the cost of issuing equity.

Hadianto (2007) empirically proves that company size has a significant negative effect on capital structure. This result is consistent with the pecking order hypothesis that for large companies, consideration of the cost of issuing equity in the capital market is quite cheap (Titman and Wessels, 1988) and the low level of information asymmetry that occurs (Smith and Warner, 1979). If this is realized, the proportion of equity ownership is greater than debt. The empirical research of Hapsari (2010), Yusron et al (2016), Wahome et al (2015), and Ramachandran \& Veeramuthu (2010), Bhawa and Made (2015), Youssef and El-Ghonamie (2015), Osarentin and Chijuka (2011), prove that a larger company size presents the cost of issuing equity in the capital market which is quite cheap so that using equity is more possible than debt.

Signaling theory, Damayanti (2015) states that large companies with high growth rates need more funds for investment activities, so that the funds obtained from retained earnings are not paid out as dividends. Zang, 2014 in Amalia, (2016), the negative correlation between dividend yield and size shows that small companies are more able to pay dividends. EmpiricallyNurhayati (2013), proves that firm size has a significant negative effect on the dividend payout ratio. The larger the size of a company, the smaller the dividend ratio.Lanawati and Amilin (2015) who prove that Firm Size has a negative sign, which means that an increase in firm size will result in a decrease in the dividend payout ratio. Other consistent results are by Winatha (2001), Damayanti and Achyani (2006) and Sulistyaningsih (2012), which conclude that the size of firm variable has a negative effect on the dividend payout ratio. Based on these explanations, research hypothesis $3(\mathrm{H} 3)$ can be formulated, namely: H2 : Firm size moderates the relationship between capital structure and dividend policy.

\section{Research Methodology}

The sample in this study were 26 companies from 65 populations of Manufacturing Companies in the Basic Industry and Chemical Sector which were listed on the Indonesia Stock Exchange in 2011-2015, which were determined by purposive technique. There are 130 observational data. The observed variable is the capital 
structure of the independent variable, measured by the debt to total asset ratio (DAR), which is the ratio between total liability and total assets, Irham Fahmi (2016). Dividend policy, as a dependent variable as measured by the dividend payout ratio (DPR), is the ratio between dividend per shre and earnings per share, Harmono (2011). The moderating variable is firm size as measured by $\ln$ total assets, Riyanto (2011). The analysis tool uses moderating regression analysis (MRA).

\section{Results}

\section{Descriptive statistics}

The results of descriptive statistical analysis were processed using the SPSS 2 statistical program 2 for each variable in 2011-2015 is presented in the following table:

Table 1 Statistics Descriptive

\begin{tabular}{lrrrrr}
\hline & N & Minimum & Maximum & Mean & $\begin{array}{c}\text { Std. } \\
\text { Deviation }\end{array}$ \\
\hline DAR & 130 &, 08 &, 92 &, 4479 &, 21028 \\
DPR & 130 &, 53 & 452.13 & 35,8358 & 46,98514 \\
FZ & 130 & 10.52 & 18.45 & 14,9260 & 1.66295 \\
Valid N (listwise) & 130 & & & \\
\hline \multicolumn{5}{c}{ Source: processed data }
\end{tabular}

In general, of the 3 variables analyzed, namely DAR, DPR, and FZ, seen from the comparison of the mean and standard deviation, almost all of them show that the mean value is greater than the standard deviation, except for DPR with a mean value of 35.84 which is lower than the standard deviation. is at 46.98. Meanwhile, seen from the comparison between the maximum value and the mean value, almost all of them show a maximum value that is greater than the mean value.

\section{Classic Assumption Test}

Normality test uses Kolmogorov Smirnov, by transforming it into a natural logarithm (Ln) as a form of treatment for data that is not normally distributed, the Kolmogorov-Smirnov test results in table 4.3 show the Asymp value. Sig has a value of $0.183>0.05$. This shows that the resulting regression model is normally distributed. Multicollinearity test using tolerance and VIF parameters shows that all independent variables do not have a very strong direct relationship (correlation). The multicollinearity test results can be seen from the tolerance value and the Variance Inflation Factor (VIF). Where the tolerance value is $>0.10$ and VIF $<10$, so it can be said that there are no symptoms of multicollinearity in the resulting regression model (Table 2).

Table 2 Classcic Assumption Test

\begin{tabular}{llll}
\hline \multicolumn{1}{c}{ TEST } & \multicolumn{1}{c}{ Parameter } & \multicolumn{2}{c}{ Result } \\
\hline Normality & Kolmogorov Smirnov & Sig $=0.183$ & \\
& & Tollerance & VIF \\
Multicoleniarity & Tollerance and VIF & LnDAR $=0.943$ & 1,060 \\
& & LnFZ $=0.612$ & 1,020 \\
Heteroscedasticity & Glejser & sigLnDAR $=0.902$ & \\
Autocorrelation & Durbin-Waston & DW $=1.759$ & \\
Linearity & Lagrange Multiflier & C2count $=130 \mathrm{x} 0.157=20.41$ \\
& & & \\
\hline
\end{tabular}

Source: processed data 
Heteroscedasticity test using the Glejser parameter, the results of the SPSS output in table 4.5 clearly showIn the regression model, there is no variance inequality of the residues from one observation to another.

This can be seen from the significance probability which is above the 5\% confidence level, so that there are no symptoms of heteroscedasticity in the resulting regression model. The autocorrelation test using the durbin-waston parameter above shows that the Durbin Watson statistical test value is 1.759. Meanwhile, the lower limit (dL) is 1.6623 , and the upper limit $(\mathrm{du})$ is 1.7589 . Thus the results obtained $(1.7589<1.759$ $<2.2411)$ were in the $\mathrm{dL}$ to $\mathrm{dU}$ area $(\mathrm{dU}<\mathrm{d}<4-\mathrm{dU})$ or were in the area not rejected, so there was no autocorrelation symptom in the resulting regression model.Linearity test, the results of the SPSS output in table 4.7 show the value of $20.41<154.302$ or C2 count $<\mathrm{C} 2$ table, it can be concluded that the resulting regression model is linear. Then the regression model can be used in this study (Table 2).

\section{Hypothesis Test}

\section{The effect of the debt to assets ratio on the dividend payout ratio}

The results of the hypothesis test (table 4.8 ) produce the $t$ value $=-0.702$ with a significance probability of 0.484 indicates a value greater than the value at the level the predetermined significance is 0.05 so that Ho is accepted or Ha is rejected. These results indicate that the Debt to Asset Ratio (DAR) has a negative and insignificant effect on the Dividend Payout Ratio (Table 3).

Table 3 Partial Test Results

\begin{tabular}{ccc}
\hline Model & Don't count & Sig \\
\hline Constant & 19,408 & 0,000 \\
LnDAR & $-0,792$ & 0.484 \\
\hline
\end{tabular}

Source: processed data

The effect of the debt to asset ratio on the dividend payout ratio, which is moderated by the firm size

The moderate variable which is the interaction between DAR * Firm Size, the $t$ value is $-4,271$ with a probability value $=0,000$ which is smaller than the specified significance level of $0.05, \mathrm{H} 3 \mathrm{Ho}$ is rejected. These results indicate that firm size negatively and significantly moderates the relationship between capital structure and dividend policy.

Table 4 Moderation Test Results

\begin{tabular}{ccc}
\hline Model & Don't count & Sig \\
\hline LnFZ & $-3,970$ & 0,000 \\
LnDAR & 4,161 & 0,000 \\
LnDAR $*$ LnFZ & $-4,271$ & 0,000 \\
\hline
\end{tabular}

Source: processed data

\section{Discussion}

The results of these studies did not match the expectations of the researchers. Results are not relevant to agency theory theory, Jensen et. al (1992) in Dewi (2008), that most of the profits will be allocated as reserves to pay off debts, the use of too high a debt will cause a decrease in dividends. Hasil also contradicts Dewi (2011), Sumiadji (2011), Vo and Nguyen (2014), and Ramachandran and Veeramuthu (2010) which proves that the divident payout ratio has a negative effect on the capital structure (table $3)$.

The results of the research match the expectations of the researchers. The results are also relevant to the pecking order theory, Smith and Warner, 1979 in Hadianto 
(2007), that because of the small information asymmetry that occurs, large companies can easily finance their investments through the capital market. The proportion of debt becomes smaller in its capital structure as funds increase through the stock capital market. The results of the study are in accordance with Hadianto (2007), Hapsari (2010), Yusron et al (2016), Wahome et al (2015), and Ramachandran \& Veeramuthu (2010),Bhawa and Made (2015),Youssef and El-Ghonamie (2015), Osarentin and Chijuka (2011), who prove that a larger company size uses equity is higher than debt (table 4). The results of the study are also relevant to the signaling theory in Damayanti (2015), that the funds obtained from retained earnings are not paid out as dividends but more funding for investment activities in large companies with high growth rates. The results also correspond toNurhayati (2013), Lanawati and Amilin (2015), (2001), Damayanti and Achyani (2006) and Sulistyaningsih (2012), which prove that the size of firm has a negative effect on the dividend payout ratio (table 4).

\section{Conclusion}

Increasing the debt ratio will not automatically increase the dividend ratio because of the low tax savings that are generated. Tax savings are an incentive for increasing the dividend ratio, because of the potential to increase company profits, which is a considered component in calculating the dividend ratio. The implication of this result is that despite the increase in interest expense and debt repayments, an increase in the debt ratio will not always have an impact on reducing the company's cash ability to pay dividends. Debt may increase, but due to low tax savings, an increase in the debt ratio does not provide a strong incentive to increase the dividend ratio.

The company's capital and operational expenditures are increasing as the size of the company increases, but it tends to use sources of funding from internal company funds, thereby reducing the debt ratio. The larger the size of the company, the higher the need for funding. Meanwhile, the source of funding needs comes from retained earnings so that more available cash is used to increase investment and company operations. This policy will reduce the dividend ratio. The implication of these results is that companies tend to choose sources of funding from the capital market (stocks) rather than from debt. The larger the size of the company, the reason is that costs are more efficient and the level of information asymmetry is low because debt is considered to increase the risk of financial distress. The results also imply that there is a tendency that the greater the size of the company, the greater the need for funds for investment and for operations. The cheapest and least risky source of funding to fulfill it is an internal source of funds, namely retained earnings. However, there are consequences that will reduce the dividend ratio.

Limited research uses one proxy for each observed variable in this study, so there is no information if other proxies are used. Future research should use more than one proxy for each research variable.The results of the research cannot be generalized for all sectors listed on the Indonesia Stock Exchange, because they have just reviewed them in Sub Basic Industry and Chemical Sector. Subsequent research expands the coverage of its population in all sectors listed on the Indonesia Stock Exchange.

\section{References}

Ambarwati, S. D. A. (2012). Advanced Financial Management. Yogyakarta: Graha Science.

Damayanti, S., \& Achyani, F. (2006). Analysis of the Influence of Investment, Liquidity, Profitability, Company Growth, and Company Size on Dividend Payout Ratio Policy. Journal of Accounting and Finance, 5(1), 51-62. 
Dewi, N. W. T., \& Sedana, I. B. P. (2012). Effect of Capital Structure, Liquidity and Growth on Dividend Policy on the IDX. Accounting Journal, 16(3). Bali: Udayana University.

Dewi, S. C. (2008). Effect of Managerial Ownership, Institutional Ownership, Debt Policy, Profitability and Company Size on Dividend Policy. Journal of Accounting and Business, 10 (1), 47-58.

Elsa. (2012). The Effect of Profitability, Asset Structure and Company Size on Capital Structure in Manufacturing Companies in the Food and Beverage Industry Listed on the Indonesia Stock Exchange (IDX).

Fahmi, I. (2013). Financial Statement Analysis. Bandung: Alfabeta.

Gita., \& Rohmawati (2010). Effect of Aktova Structure, Profitability, Dividend Policy on Capital Structure in Banks Listed on the Indonesia Stock Exchange in 20052009. AKRUAL, 2(1), 76-91. e-ISSN: 2502-6380

Hadianto, B. (2007). The Effect of Asset Structure, Company Size, and Profitability on the Capital Structure of Issuers in the Indonesian Telecommunications Sector 2000-2006: A Pecking Order Hypothesis Testing. Management Journal, 7(2).

Halim, A. (2015). Investment Analysis in Financial Assets. Mitra Wacana Media. Jakarta.

Hanafi, M. (2004). Financial Management. Yogyakarta: BPFE.

Husnan, S., \& Pujiastuti, E. (2002). Management Basics ( $3^{\text {rd }}$ Edition). Yogyakarta: UPP-AMP YKPN.

Karadeniz. et al. (2009). Determinants of Capital Structure: Evidence from Turkish Lodging Companies. International Journal of Contemporary Hospitality Management, 21(5), 594-609.

Cashmere. (2012). Financial Statement Analysis. Jakarta: Rajawali Press.

Khoiro, E. E. U, Suhadak., \& Handayani, S. R. (2013). The Influence Of Capital Structure And Firm Size On Profitability And Devidend Policy (An Empirical Study at Property and Real Estate Sector Listed in Indonesia Stock Exchange during the periods of 2009-2012.

Lanawati., \& Amilin. (2015). Cash Ratio, Debt to Equity Ratio, Return on Asset, Firm Size, Growth and Dividend Payout Ratio in Manufacturing Companies in Indonesia. Journal of Financial Science and Research, 7(6).

Levy, H., \& Sarnat, M. (1990). Capital Investment and Financial Decisions (4 $^{\text {th }}$ edition). Prentice Hall Inc.

Maidah, I. (2016). The Effect of Profitability, Asset Structure, and Company Size Affecting the Capital Structure of Trading Companies on the IDX. Journal of Financial Science and Research, 5(7). ISSN 2461-0593.

Mulyawan, S. (2015). Financial Management. Bandung: CV.Pustaka Setia.

Najmudin. (2011). Financial Management and Modern Syar'iyyah Actualization. Yogyakarta: Andi.

Nurhayati, M. (2013). Profitability, Liquidity and Company Size Impact on Dividend Policy and Non-Service Sector Firm Value. Journal of Finance and Business, $5(2)$. 
Nursandari, M. (2013). Analysis of Factors Affecting Dividend Policy with Size as a Moderation Variable in Manufacturing Companies Listed on the Indonesia Stock Exchange. [Thesis]. Yogyakarta: Yogyakarta State University

Osarentin, I. S., \&. Chijuka, I. M. (2011). The Determinants of Capital Structure of Losted Firms In Nigeria. European Journal of Accounting Auditing and Finance Research, 2(10), 96-111.

Raharjaputra, H. (2011). Practical guide to Financial Management and Accounting for Corporate Executives. Jakarta: Four Salemba.

Riyanto, B. (2011). Basics of company spending (4 $4^{\text {th }}$ edition). Yogyakarta: BPFE Yogyakarta.

Siswantini, W. (2014). The Effect of Financial Ratio Analysis on, Vol 2, No.1, 2009, pages 1-6. Dividend Policy (Empirical Study on Real Estate Companies and Property Listed on the Indonesia Stock Exchange). Journal of Organization and Management, 10(2), 136-147.

Sulistyowati, A, Suhadak., \& Husaini, A. (2013). The effect of capital structure on dividend payments (studies on companies listed on the Indonesia Stock Exchange 2010-2012). Malang: Universias Brawijaya.

Sumiadji. (2011). Analysis of financial variables that affect dividend policy accounting dynamics journal, Vol 3 no. 2 ISSN 2085-4277. State University of Malang, Indonesia.

Sunarto., \& Agus (2009). The Effect of Leverage, Size and Company Growth on Profitability. TEMA Journal 6(1), 86-103.

Tariq. (2015). The Joint Determinants of Leverage and Dividend Policy: A Balanced Panel Study of Non Financial Firms of India and Pakistan. Rhine-Waal University of Applied Sciences / Germany. European Scientific Journal, 11(10). ISSN: 1857 - 7881 (Print) e - ISSN 1857- 7431.

Veeramuthu, R. (2010). The Impact of Firm Size on Dividend Behavior: A Study With Reference to Corporate Firms across Industries in India. Managing Global Transitions, 8(1).

Vo, D. H., \& Nguyen, V. T. Y. (2014). Managerial ownership, leverage, and dividend policies: Empirical evidence from Vietnam Listed Firm. International Journal of Economics and Finance, 6(5). ISSN 1916 - 971X.

Youssef, E. (2015). Factors That Determine Capital Structure in Building Materials and Construction Listed Firms: Egypt Case. International Journal of Financial Research, 6(4).

Zhang, X. (2014). Does Ownership Structure Matter for Dividend Yield? Evidence from the Hongkong Stock Exchange. Business and Economic Research, 4(2). ISSN 2162-486. 